\title{
Comparative study of hypoglycaemic activity of morus alba with oral hypoglycaemic drug (metformin) in alloxan induced diabetic rats
}

\author{
Naveen Kumar Madalageri*, Lavanya Nagaraj
}

Department of Pharmacology, Sree Narayana Institute of Medical Science, Ernakulam, Kerala, India

Received: 02 November 2016 Accepted: 07 November 2016

*Correspondence to:

Dr. Naveen Kumar Madalageri, Email:

dr.naveen.madalageri@gmail. com

Copyright: (C) the author(s), publisher and licensee Medip Academy. This is an openaccess article distributed under the terms of the Creative Commons Attribution NonCommercial License, which permits unrestricted noncommercial use, distribution, and reproduction in any medium, provided the original work is properly cited.

\begin{abstract}
Background: Diabetes mellitus is a spectrum of common metabolic disorders, arising from a variety of pathogenic mechanisms, all resulting in hyperglycemia. The number of individuals with diabetes is rising rapidly throughout the world. Worldwide the prevalence of diabetes mellitus is estimated to be $2.8 \%$ and is set to rise to $4.4 \%$ by 2030 . In India alone, the prevalence of diabetes is expected to increase from 30.9 million to 69.9 million by 2025 . Despite the availability of many drugs for treatment for diabetes and its complications continue to be major medical problems. Currently available antidiabetic drugs are not completely effective and are associated with adverse effects both in the short and long run. Some studies have reported many different medicinal properties of mulberry leaves (Morus alba) like neuroprotective property, cardioprotective property, antidepressant property. It is used as anti-inflammatory, diuretic, expectorant and antidiabetic in traditional Chinese medicine. So this study is undertaken to evaluate the hypoglycaemic effect of aqueous extract of leaves of Morus alba in Alloxan induced diabetic albino rats.
\end{abstract}

Methods: Total 24 albino rats of either sex weighing 150-200 gms were selected and randomly divided into 4 equal groups containing 6 rats in each group. First group (Non-diabetic control) was given normal saline $(0.5 \mathrm{~mL})$. Other 3 groups were induced diabetes by giving Alloxan $(150 \mathrm{mg} / \mathrm{kg} \mathrm{IP})$. They were subdivided into diabetic control group receiving normal saline $(0.5 \mathrm{~mL})$, standard control group receiving Metformin (10 $\mathrm{mg} / \mathrm{kg}$ body weight) and test group receiving Morus alba extract $(600 \mathrm{mg} / \mathrm{kg})$. Fasting blood sugar level was estimated on day $0,1,3,7,14,21$ and 28 by using glucometer. Data were statistically analysed by Tukey's Post Hoc test and ANOVA.

Results: Morus alba at the above doses significantly reduced blood glucose levels as compared to control group $(\mathrm{p}<0.01)$, but as compared to standard drugs (Metformin) it is statistically insignificant ( $\mathrm{p}>0.05)$.

Conclusions: The result suggests that Morus alba leaves have hypoglycaemic activity.

Keywords: Albino rats, Alloxan, Hypoglycaemia, Metformin, Morus alba

\section{INTRODUCTION}

Diabetes mellitus is a spectrum of common metabolic disorders, arising from a variety of pathogenic mechanisms, all resulting in hyperglycemia. The number of individuals with diabetes is rising rapidly throughout the world. Both genetic and environmental factors contribute to its pathogenesis, which involves insufficient insulin secretion, reduced responsiveness to endogenous or exogenous insulin, increased glucose production, and/or abnormalities in fat and protein metabolism. ${ }^{1}$

Chronic hyperglycemia leads to number of complications- cardiovascular, renal, neurological and ocular and others such as intercurrent infections. Currently the number of cases of diabetes worldwide is estimated to be around 150 million. This number is predicted to double by 2025 , with the greatest number of cases being expected in China and India. ${ }^{2,3}$ 
Worldwide the prevalence of diabetes mellitus is estimated to be $2.8 \%$ ad is set to rise to $4.4 \%$ by 2030 . The greatest relative rise is predicted in developing countries of the Middle Eastern crescent, sub-Saharan Africa and Indian subcontinent. By the year 2030, over $85 \%$ of world's diabetic patients will be in developing countries. In India alone, the prevalence of diabetes is expected to increase from 30.9 million to 69.9 million by $2025 .^{4}$

The picture in India is much more alarming. The current estimation shows that there are 3.5 crore people with diabetes and this number is likely to raise upto 5.72 crore by 2025 . India has now been declared by WHO as the 'Diabetes capital of the world'.

Despite the availability of many drugs for treatment for diabetes and its complications continue to be major medical problems. Currently available antidiabetic drugs are not completely effective and are associated with adverse effects both in the short and long run. ${ }^{5}$

Several herbs have been tried in various studies with the aim to prevent or delay type 2 diabetes. Aegle marmelose, Aloe vera, Artemisia pallens, Coccinia indica \& many others have been shown to have antidiabetic activity. ${ }^{6-8}$

Some studies have reported many different medicinal properties of mulberry leaves (Morus alba) like neuroprotective property, cardioprotective property, antidepressant property. $^{9-11}$ It is used as antiinflammatory, diuretic, expectorant and antidiabetic in traditional Chinese medicine. ${ }^{12-14}$

So this study is undertaken to evaluate the hypoglycaemic effect of aqueous extract of leaves of Morus alba in Alloxan induced diabetic albino rats.

\section{METHODS}

The study was conducted at Department of Pharmacology, J. J. M. Medical College, Davangere, after the approval from Institutional Animal Ethics Committee.

\section{Materials}

\section{Animals}

Animals used were albino rats, of Wistar strain, weighing between 150-200gm of either sex.

\section{Chemicals}

1. Alloxan Monohydrate: Alloxan monohydrate dissolved in $0.9 \%$ sodium chloride solution (normal saline) is used in this study.

2. Sodium Chloride: It is used to prepare normal saline in distilled water.
3. Metformin: Metformin belongs to Biguanides group of oral antidiabetic drugs. In this study it is taken as the standard drug and results are compared with test group.

4. Morus Alba: The aqueous extract of leaves was procured from Natural remedies, Bangalore. The extract was used at doses of $600 \mathrm{mg} / \mathrm{kg}$. The solution was freshly prepared by dissolving the aqueous extract in normal saline on the day of experiment and administered by oral route.

\section{Equipment}

1. Rat Feeding Needle: Metallic feeding tube used for oral administration of the drugs.

2. Tuberculin Syringe: Used for injecting Alloxan into peritoneal cavity and for administering the drug at proper dosage.

3. Insulin Syringe: For drawing blood from tail vein of rats.

4. Glucometer: The glucometer used in this study is the Optium Xceed Sensor from Abbott Diabetes Care Ltd.

\section{Inclusion criteria}

- Animals weighing 150-200gms.

- $\quad$ Age 3-4 months.

- Healthy with normal behavior and activity.

\section{Exclusion Criteria}

- Animals weighing more than $200 \mathrm{gms}$ and less than $150 \mathrm{gms}$.

- $\quad$ Age $<3$ months and $>4$ months.

- Pregnant females and those which have delivered.

In the present study, diabetes was chemically induced using Alloxan to produce hyperglycaemia in rats. Here the Alloxan monohydrate was administered intraperitoneally under aseptic precaution to induce diabetes mellitus 5 days before the experiment. The blood glucose was measured with the help of Glucometer.

A total of 24 animals $(n=24)$ were used. They were divided into 4 groups of 6 animals each. They were housed in cages containing wooden shavings with 6 animals per cage. Animals were randomly housed at a controlled temperature of $21^{\circ} \mathrm{C} \pm 3^{\circ} \mathrm{C}$, with a 12-hour light: 12-hour dark cycle. The animals had free access to standard pellet and water. Out of 24 rats, 18 rats were induced diabetes.

\section{Induction of diabetes}

Following an overnight fast, 18 rats were injected intraperitoneally with freshly prepared Alloxan monohydrate $(2 \%$ solution, dissolved in $0.9 \%$ sodium chloride) in a dose of $150 \mathrm{mg} / \mathrm{kg}$ body weight. 
Animals were carefully observed for first 24 hours following the injection for any evidence of allergic reactions, behavioural changes, convulsions and hypoglycaemic attacks. No untoward reaction was observed in any animal.

Blood glucose level was recorded daily morning at around 9.00 a.m. for 1 week. Animals developed stable hyperglycaemia after 5 days. Only those animals with blood glucose level more than $250 \mathrm{mg} / \mathrm{dL}$ were selected for the study. Later they were divided into 3 groups: Diabetic control group, Standard control group, and Test group. Animals which were not given Alloxan to induce diabetes were considered as Non-diabetic control group.

\section{Non-diabetic control group (group 1)}

Here, non-diabetic normal animals which have not received Alloxan were taken as control group for study. Animals were fed with $0.5 \mathrm{~mL}$ of normal saline daily for 28 days through oral route. Blood glucose levels were recorded on 0 day before the administration of normal saline, then on $1^{\text {st }}, 3^{\text {rd, }} 7^{\text {th }}, 14^{\text {th }}, 21^{\text {st }}$, and $28^{\text {th }}$ days.

\section{Diabetic control group (group 2)}

The blood glucose levels of diabetic animals of this group were recorded at around 9 am before giving normal saline. This value was considered as blood glucose value of 0 day. Later the animals were fed with $0.5 \mathrm{~mL}$ normal saline orally, daily in the morning for 28 days. Blood glucose levels were recorded on $1^{\text {st }}, 3^{\text {rd, }} 7^{\text {th }}, 14^{\text {th }}, 21^{\text {st }}$, and $28^{\text {th }}$ days. Animals were observed carefully for the evidence of any behavioural changes, hyperglycaemia, convulsions, etc.

\section{Standard group (group 3)}

The blood glucose levels of diabetic animals of this group were recorded at around 9 am before the administration of the standard drug Metformin in a dose of $10 \mathrm{mg} / \mathrm{kg}$ body weight suspended in normal saline orally. This value was considered as blood glucose value of 0 day. Later the animals were fed with Metformin 10mg/ kg body weight suspended in normal saline orally, daily in the morning for 28 days. Blood glucose levels were recorded on $1^{\text {st }}, 3^{\text {rd, }} 7^{\text {th }}, 14^{\text {th }}, 21^{\text {st }}$, and $28^{\text {th }}$ days. Animals were observed carefully for the evidence of any behavioral changes, hypoglycemia, convulsions etc.

\section{Test group (group 4)}

The blood glucose levels of diabetic animals of this group were recorded at around 9 am before the administration of the test drug Morus alba $600 \mathrm{mg} / \mathrm{kg}$ body weight suspended in normal saline; this value was considered as blood glucose value of 0 day. Later the animals were fed with Morus alba extract in a dose of $600 \mathrm{mg} / \mathrm{kg}$ body weight, daily in the morning for 28 days. Blood glucose levels were recorded on $1^{\text {st }}, 3^{\text {rd, }} 7^{\text {th }}, 14^{\text {th }}, 21^{\text {st }}$, and $28^{\text {th }}$ days. Animals were observed carefully for the evidence of any behavioural changes, hypoglycaemia and convulsions.

\section{RESULTS}

Table 1 and Figure 1 show the variation in blood glucose levels on day 0 to day 28 in each group. Mean blood glucose levels in non-diabetic control group varied from 59.7 to $67.7 \mathrm{mg} / \mathrm{dL}$ without much of variation during the study.

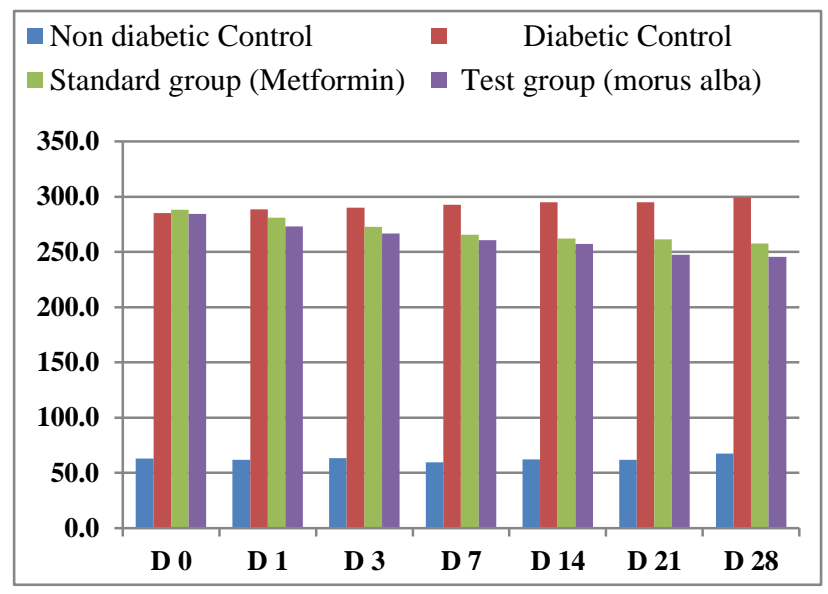

Figure 1: Day wise variation in mean blood glucose levels in various study groups.

Table 1: Mean \pm SD values of blood glucose levels in different groups.

\begin{tabular}{|c|c|c|c|c|c|c|c|}
\hline Groups & D0 & D1 & D3 & D7 & D14 & D21 & D28 \\
\hline $\begin{array}{l}\text { 1. Non diabetic } \\
\text { control }\end{array}$ & $63.0 \pm 8.4$ & $62.0 \pm 7.2$ & $63.3 \pm 8.5$ & $59.7 \pm 7.5$ & $62.3 \pm 6.1$ & $62.0 \pm 7.7$ & $67.7 \pm 6.6$ \\
\hline 2. Diabetic control & $285.3 \pm 11.8$ & $288.7 \pm 15.7$ & $290.0 \pm 11.9$ & $292.7 \pm 11.8$ & $295.0 \pm 11.8$ & $295.0 \pm 11.2$ & $299.0 \pm 13.6$ \\
\hline $\begin{array}{ll}\text { 3. Standard group } \\
\text { (Metformin) }\end{array}$ & $288.3 \pm 15.1$ & $281.0 \pm 12.9$ & $272.7 \pm 14.3$ & $265.7 \pm 10.3$ & $262.0 \pm 15.5$ & $261.3 \pm 10.6$ & $257.7 \pm 8.9$ \\
\hline $\begin{array}{ll}\text { 4. } & \text { Test group } \\
\text { (morus alba) }\end{array}$ & $288.3 \pm 14.3$ & $277.7 \pm 16.2$ & $271.0 \pm 13.6$ & $263.7 \pm 12.9$ & $258.7 \pm 12.9$ & $250.0 \pm 8.3$ & $247.0 \pm 6.5$ \\
\hline $\begin{array}{l}\text { Gr. } 1 \text { (control) v/s } \\
\text { Gr. } 2,3,4,\end{array}$ & $\mathrm{P}=0.000$ & $P=0.000$ & $P=0.000$ & $\mathrm{P}=0.000$ & $P=0.000$ & $P=0.000$ & $P=0.000$ \\
\hline
\end{tabular}


In diabetic control group, there was a gradual increase in blood glucose levels from mean value of $285.3 \pm 11.3$ $\mathrm{mg} / \mathrm{dL}$ on day 0 to $299.0 \pm 13.6 \mathrm{mg} / \mathrm{dL}$ on day 28 .

In standard group (Metformin), there was gradual decrease in blood glucose level from $288.3 \pm 15.1 \mathrm{mg} / \mathrm{dL}$ on day 0 to $257.7 \pm 8.9 \mathrm{mg} / \mathrm{dL}$ on day 28 .

In test group, there was gradual decrease in blood glucose level from $288.3 \pm 14.3$ on day 0 to $247 \pm 6.5$ on day 28 , which was statistically significant compared to control.
Table 2 and 3 gives statistical analysis of the results on day $0,1,3,7,14,21$ and 28 using one-way ANOVA followed by Tukey's Post Hoc test. The 'P' value of $<0.05$ was considered significant. In ANOVA test, comparison of mean blood glucose levels between the groups was significant from day 3 till the end of study. In Post Hoc Tukey's test, comparison of mean reduction in blood glucose in test group (Morus alba) with that of diabetic control group was significant $(\mathrm{P}<0.05)$ from day seven. However, with respect to standard control group (Metformin), it was statistically insignificant $(\mathrm{P}>0.05)$.

Table 2: Statistical analysis showing comparison of mean blood glucose levels between different groups on different days by using one way ANOVA test.

\begin{tabular}{|llllllll|}
\hline Groups & D0 & D1 & D3 & D7 & D14 & D21 & D28 \\
\hline 1. Diabetic control & $285.3 \pm 11.8$ & $288.7 \pm 15.7$ & $290.0 \pm 11.9$ & $292.7 \pm 11.8$ & $295.0 \pm 11.8$ & $295.0 \pm 11.2$ & $299.0 \pm 13.6$ \\
\hline $\begin{array}{l}\text { 2. Standard group } \\
\text { (Metformin) }\end{array}$ & $288.3 \pm 15.1$ & $281.0 \pm 12.9$ & $272.7 \pm 14.3$ & $265.7 \pm 10.3$ & $262.0 \pm 15.5$ & $261.3 \pm 10.6$ & $257.7 \pm 8.9$ \\
\hline $\begin{array}{l}\text { 3. Test group } \\
\text { (morus alba) }\end{array}$ & $288.3 \pm 14.3$ & $277.7 \pm 16.2$ & $271.0 \pm 13.6$ & $263.7 \pm 12.9$ & $258.7 \pm 12.9$ & $250.0 \pm 8.3$ & $247.0 \pm 6.5$ \\
\hline F- Value & 0.094 & 0.848 & 3.735 & 11.506 & 15.734 & 32.365 & 44.221 \\
\hline Significance & $\mathrm{P}=0.911 \mathrm{NS}$ & $\mathrm{P}=0.448 \mathrm{NS}$ & $\mathrm{P}=0.048 \mathrm{~S}$ & $\mathrm{P}=0.001 \mathrm{~S}$ & $\mathrm{P}=0.000 \mathrm{~S}$ & $\mathrm{P}=0.000 \mathrm{~S}$ & $\mathrm{P}=0.000 \mathrm{~S}$ \\
\hline
\end{tabular}

Table 3: Statistical analysis showing comparison of mean blood glucose levels between different groups on different days by using post-hoc Tukey's test.

\begin{tabular}{|c|c|c|c|}
\hline Days & Groups compared & Mean diff. & P - value* \\
\hline \multirow{3}{*}{3} & $2-3$ & 17.3333 & $0.095 \mathrm{NS}$ \\
\hline & $2-4$ & 19.0000 & $0.064 \mathrm{NS}$ \\
\hline & $3-4$ & 1.6667 & $0.975 \mathrm{NS}$ \\
\hline \multirow{3}{*}{7} & $2-3$ & 27.0000 & $0.003, \mathrm{~S}$ \\
\hline & $2-4$ & 29.0000 & $0.002, \mathrm{~S}$ \\
\hline & $3-4$ & 2.0000 & $0.953, \mathrm{NS}$ \\
\hline \multirow{3}{*}{14} & $2-3$ & 33.0000 & $0.001, \mathrm{~S}$ \\
\hline & $2-4$ & 36.3333 & $0.000, \mathrm{~S}$ \\
\hline & $3-4$ & 3.3333 & $0.888, \mathrm{NS}$ \\
\hline \multirow{3}{*}{21} & $2-3$ & 33.6667 & $0.000, \mathrm{~S}$ \\
\hline & $2-4$ & 45.0000 & $0.000, \mathrm{~S}$ \\
\hline & $3-4$ & 11.3333 & $0.160, \mathrm{NS}$ \\
\hline \multirow{3}{*}{28} & $2-3$ & 41.3333 & $0.000, \mathrm{~S}$ \\
\hline & $2-4$ & 52.0000 & $0.000, \mathrm{~S}$ \\
\hline & $3-4$ & 10.6667 & $0.195, \mathrm{NS}$ \\
\hline
\end{tabular}

Figure 2 shows comparison of mean blood glucose levels between standard and test groups, which are recorded in the fixed intervals as detailed in Table 1. It indicates that the test drug has similar hypoglycaemic action when compared to the standard group.

Overall mean percentage reduction of glucose was higher with test group (14.3\%) compared to standard control group $(10.61 \%)$.

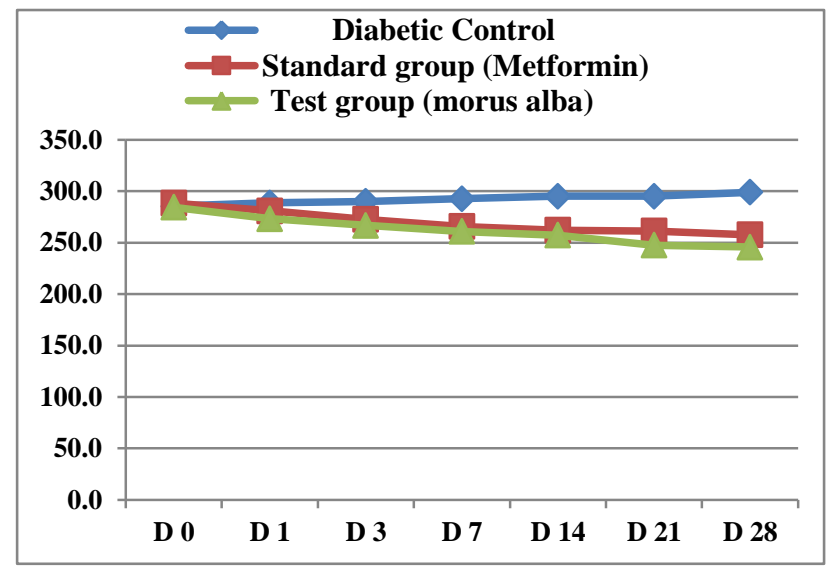

Figure 2: Variation in blood glucose levels from day 0 to day 28 in study groups.

\section{DISCUSSION}

Study done by Bahman Nickavar and Study done by M. Saeed Arayne et al shown that methanolic extract of Morus alba leaves have hypoglycemic activity and probably Morus alba has action on $\beta$ cells of pancreas. ${ }^{15}$

Golboo Mosazadeh has shown that Morus alba leaves extract has significant inhibitory activity on $\alpha$ amylase enzyme. ${ }^{16}$

Study conducted by Jamshid Mohammadi and Prakash R Naik shown that Morus alba leaves extract has 
hypoglycemic activity in wistar rats as compared to control rats.

Study done by Andallu B, Vardacharyulu NC shown that Fasting blood glucose levels in diabetic mulberry treated group were reduced significantly $(\mathrm{P}<0.01)$ by $50 \%$ when compared to diabetic control, while a $28 \%$ decrease was only noticed in Glibenclamide treated group, which indicated that mulberry leaves were more effective in controlling hyperglycemia than the oral hypoglycemic drug Glibenclamide. ${ }^{12}$

In this study the hypoglycemic action of aqueous extract of Morus alba leaves have been evaluated and its efficacy has been compared with that of standard oral anti diabetic drug Metformin Aqueous extract of Morus alba leaves $(600 \mathrm{mg} / \mathrm{kg})$ have decreased blood glucose level from $288.3 \mathrm{mg} / \mathrm{dL}$ on day 0 to $247.0 \mathrm{mg} / \mathrm{dL}$ on day 28 . Hypoglycaemia produced by Morus alba extract was significant $(\mathrm{p}<0.05)$ when compared to control group from day 3 to day 28 . The percent reduction of blood glucose level during study period was $14.3 \%$ as compared to Metformin group (10.61\%). As compared to Metformin group, Morus alba group has similar reduction in mean percent blood glucose level, but it was statistically insignificant ( $\mathrm{p}>0.05)$.

The present study has several limitations. The study has been carried out only in one species of animals viz "rats" and needs to be extended to other animals as well. Only the fasting blood glucose was estimated in this study which does not give a clear picture about the effect of Morus alba on other parameters of diabetes mellitus. No attempt was made to establish exact mechanism of hypoglycaemic activity and $\beta$ cell pathology. In present study we have used single dose of $600 \mathrm{mg} / \mathrm{kg}$ as a testing dose. Further studies need to be done to fix proper dosage. Acute and chronic toxicity testing need to be undertaken. Sample size in the present study is small, hence further study needed to confirm the outcome of the present study.

\section{ACKNOWLEDGEMENTS}

We are thankful to Dr. Somashekar H.S., M.D., (Professor and H.O.D., Department of Pharmacology, JJMMC), Dr. H. S. Siddappa Devaru M.D., Dr. Nagabhushan A M.D., Dr. S. Y. Kattimani M.D., Dr. Shashikala G.H., M.D. (Professors of Pharmacology), Dr. Narendranath S., M.D., (Associate Professor in Pharmacology) Dr. Jyothi C.H., M.D., Dr. Geetha M.D. (Reader in Pharmacology), Dr. Suneel Kumar Reddy M.D., Dr. Kiran L.J., M.D., Dr. Shivshankar Murthy M.D. and Dr. Srinivas L.D., M.D. (Assistant Professors) for their kind support throughout the study. We are also thankful to Dr. Abhishek A, Dr. Prabhakar A and Dr. Gokul C.G. for their continuous cooperation during present study.
Funding: No funding sources

Conflict of interest: None declared

Ethical approval: The study was approved by the Institutional Ethics Committee

\section{REFERENCES}

1. Alvin C. Powers, David D'Alessio, Endocrine Pancreas and Pharmacotherapy of Diabetes Mellitus and Hypoglycemia. The pharmacological basis of therapeutics. Goodman and Gilman.12th ed. Mc Graw-Hill; 2011:1243.

2. Park K. Diabetes mellitus. Parks textbook of preventive and social medicine. 18th edi. Jabalpur: M/S Banarsidas Bhanot Publishers; 2005:312.

3. Madalageri NK, Nagaraj L, Nidamarthi SB. Evaluation and comparative study of hypoglycaemic activity of morus alba with oral hypoglycaemic drug (glibenclamide) in alloxan induced diabetic rats. J. Evolution Med. Dent. Sci. 2016;5(48):3062-5.

4. Raheja BS, Kapor A, Bhaskar A, Sathe SR, Jorgensen LN, Moorthi SR. Diabetes care in Indiacurrent studies. JAPI. 2001;49(7):712-22.

5. Mohammadi J, Naik PR. Evaluation of hypoglycemic effect of Morus alba in an animal model. Indian $\mathbf{J}$ Pharmacology. 2008;40(1):15-8.

6. Padwal R, Varney J, Majumdar AR, McAlistar FA, JA Johnson. Diabetes Care. 2005;28(3):736-44.

7. Benny, Abraham K, Adithan C. Indian J Pharmacol. 2000;32:S67-80.

8. Yeh GY, Kaptchuk JJ, DM Eisenberg, Phillips RS. Diabetes Care. 2003;26:1277-94.

9. Kang TH. Enhancement of Neuroprotection of Mulberry leaves (Morus alba L) prepared by the Anaerobic treatment against ischemic damage. Biol Pharm Bull. 2006;29:270-4.

10. Enkhmaa. Mulberry (Morus alba L) leaves and major flavonal Quercetin 3-(6-malonylglucaside) attenuate Atherosclerotic Lesion development in LDL receptor- deficient mice. J Nutr. 2005;135:729-34.

11. Sattayasi J, Tiamkao S, Puapairoj P. Biphasic effect of Morus alba Leaves (Green Tea) Extracton Micein Chronic Forced Swimming Model. Phytother. Res. 2008;22:487-92.

12. Andallu B, Suryakantham V, Lakshmi B, Reddy GK. Effect of mulberry ( Morus indica L.) therapy on plasma and erythrocyte membrane lipids in patients with type 2 diabetes. Clin Chim Acta. 2001;314:4753.

13. Andallu B, Varadacharyulu N. Control of hyperglycemia and retardation of cataract by mulberry (Morus indica L.) leaves in streptozotocin diabetic rats. Indian J Exp Biol. 2002;40:791-5.

14. Andallu B, Varadacharyulu N. Antioxidant role of mulberry (Morus indica L.cv. Anantha) leaves in streptozotocin diabetic rats. Clin Chim Acta. 2003;338:3-10.

15. Saeed arayne M. In vitro hypoglycemic activity of methanolic extract of some indigenous plants, Pak. J. Pharm Sci. 2007;20(4):261-8. 
16. Nickavara B, Mosazadeha G. Influence of Three Morus Species Extracts on $\alpha$-Amylase Activity. Iranian Journal of Pharmaceutical Research. 2009;8(2):115-9.
Cite this article as: Madalageri NK, Nagaraj L. Comparative study of hypoglycaemic activity of morus alba with oral hypoglycaemic drug (metformin) in alloxan induced diabetic rats. Int $\mathbf{J}$ Basic Clin Pharmacol 2016;5:2362-7. 